Original Research

\title{
Spatiotemporal Patterns and Drivers of Land Use and Land Cover Change in the China-Mongolia-Russia Economic Corridor
}

\author{
Suocheng Dong ${ }^{1,2}$, Yijia Li ${ }^{1,2}$, Yu Li ${ }^{1,2, *}$, Shifeng $\mathrm{Li}^{3}$ \\ ${ }^{1}$ Institute of Geographic Sciences and Natural Resources Research, Chinese Academy of Sciences, \\ Beijing 100101, China \\ ${ }^{2}$ College of Resources and Environment, University of Chinese Academy of Sciences, Beijing 100049, China \\ ${ }^{3}$ College of Water Resources \& Civil Engineering, China Agricultural University, Beijing 100083, China
}

Received: 8 April 2020

Accepted: 9 September 2020

\begin{abstract}
The China-Mongolia-Russia Economic Corridor (CMREC) is the key comprehensive strategic area of the "Belt and Road Initiative (BRI)" that would directly accelerate the impact of human activities on land use and land cover change (LUCC). The study firstly clarified LUCC and environmental and socioeconomic driving factors in the CMREC from 1992 to 2015. It will help face the challenges of multinational sustainable development and take more targeted measures with cooperation. The results showed that the ecological environment deteriorated in the CMREC with increasing cropland, unused land, urban areas and grassland. Forest was the largest source of unused land, and urban areas consistently expanded into other areas. Compared with Mongolia and Russia, China had the highest rate of urbanization (19.68\%) and experienced a prominent increase in forest revegetation $(0.25 \%)$. LUCC mostly occurred along the railways, highways and rivers adjacent to vulnerability gravity centres. Overall, the relative importance of socioeconomic factors was higher than that of the environment, and railway was the most important factor. In the long term, human activity, especially national-level policy, had a direct and even far-reaching impact on LUCC.
\end{abstract}

Keywords: China-Mongolia-Russia economic corridor (CMREC), land use and land cover change (LUCC), driving factors, landscape vulnerability, GIS

*e-mail: liy@igsnrr.ac.cn 


\section{Introduction}

Land use and land cover change (LUCC) is a universal phenomenon that affects global climate change, earth system functioning and the sustainable development of human society from local to global scales [1-3]. Land cover (i.e., the biophysical attributes of the earth's surface) and land use (i.e., human uses and changes to these attributes) are two of the most important factors that contribute to the degradation of environmental conditions [4-6]. United Nations Sustainable Development Goals (SDGs) of 2030 Agenda-Goal 15 underlined "sustainably manage forests, combat desertification, halt and reverse land degradation, halt biodiversity loss". With the growth of the human population and level of resource use, human activities in agriculture, industry, fishing and international commerce have impacts on land transformation (e.g., through forestry, grazing and urbanization) $[3,7]$. The change driven by human activities leads to landscape fragmentation, enhances the greenhouse accelerates, accelerate soil degradation [8] and affects the ability of ecosystems to support the sustainable development of human society $[1,9]$. These trends are observed worldwide, such as in Europe (Poland, Spain) [10-13], in Asia (Thailand, China, Russia, Mongolia) [14-18], in North American (United States, Mexico)[19-21]. In fact, analyses of accurate, relevant and continual information on the land cover dynamics of LUCC are urgently needed.

Landscape vulnerability is used to evaluate the stability and succession of land cover when it is affected by an external disturbance [22]. Different land cover classes have different characteristics in terms of maintaining landscape function, protecting biodiversity and preventing soil degradation [23]. LUCC is not only a temporal process; more importantly, it can reflect the level of human interference in spatial different regions where decision-makers implement national policy to change the land cover. In these regions, the ecological effect of LUCC is most severe, leading to landscape vulnerability and arousing a series of environmental issues. In 1872, the centre of gravity concept was first used in population issues in the United States [24]. The concept was derived from physics and referred to the point at which the distribution would balance if it was represented by weighted points on a weightless line, plane, or sphere [25]. Since its introduction, the centre of gravity concept has been widely used in the study of geographic distributions [26]. Over time, although most studies determined the temporal trends of LUCC, few studies have focused on the spatial features, discerning the vulnerability gravity centre of LUCC at the land cover grid scale. This information is critical for decision-makers to formulate the spatial strategy of land management in the most efficient way.

The driving factors of LUCC are mainly divided into socioeconomic and environmental domains [6]. Currently, LUCC research pays more attention to the quantitative mechanism analysis of drivers [6, 17] than to historical trends and patterns [27]. Moreover, existing research on driving forces rooted in statistical methods [17] and qualitative analysis is complicated and time-consuming with many additional variables $[6,28]$. Random forest (RF) is an ensemble treestructured classifier that generates a large number of classification trees and votes for the most popular class to make a prediction [29]. RF is already widely used due to its competitive classification and regression results and its processing speed [30,31]. Furthermore, it is used to select and rank variables, which is critical for discriminating variables and assessing their relative importance [29, 32]. Nevertheless, most LUCC studies have used RF to focus on land cover classification of satellite sensor imagery [33-35]. Less research has used RF to identify and rank the driving factors of LUCC. This information could be used to quantitatively describe the socioeconomic or environmental factors that play crucial roles in the LUCC process.

The "Belt and Road Initiative (BRI)" was announced by President Xi Jingping in 2013 during his visit to Kazakhstan and Indonesia [36]. BRI refers to "the Silk Road Economic Belt and the $21^{\text {st }}$ Century Maritime Silk Road", which spans approximately 65 countries and affects more than two-thirds of the world's population and nearly $30 \%$ of the global gross domestic product (GDP) [37]. It is a global win-win cooperation that aims to advocate the concepts of low-carbon, recycling, sustainable production, sustainable lifestyles, stronger ecological and environmental cooperation and promotion of ecological civilization, with the objective of jointly achieving the 2030 sustainable development goals [38-40]. The China-Mongolia-Russia Economic Corridor (CMREC) is one of six important core corridors of the BRI. Furthermore, it is the first multilateral cooperation plan that officially launched to form part of the BRI in 2015. The CMREC aims to align China's BRI with the "Eurasian Economic Union" proposed by Russia and Mongolia's "Steppe Road Program" (which aims to reinvigorate the economy by improving transport and trade) [41]. The CMREC plans to promote transportation infrastructure and connectivity, including modernizing current railways and building new railways and highways [42]. To obtain this win-win cooperative effort, the BRI must be built based on transnational studies rather than being limited to one country. With the constant promotion of the BRI, human activity will place more pressure on the ecosystem and accelerate the LUCC along the CMRECTo develop guidelines for the planning of CMREC, we need research that focuses on LUCC pattern, uses remote sensing landscape data, GIStechniques, computer simulation and spatial modelling to identify critical impact. In this study, we aim to 1) focus on multinational corridors to clarify and compare the temporal patterns of LUCC from 1992 to $2015 ; 2$ ) identify the vulnerability gravity centre of LUCC using a spatial gravity model; and 3) classify 
the vulnerability grades of LUCC and quantitatively rank the relative importance of socioeconomic and environmental driving factors with RF. This study will allow us to understand the process of LUCC under the influence of human society and environment [43, 44] and help with the development of more targeted policy to protect the ecological environment, advance the multilateral cooperation and promote the sustainable development of the CMREC.

\section{Materials and Methods}

\section{Study Area}

The study area $\left(39^{\circ} 34^{\prime} \mathrm{N} \sim 58^{\circ} 12^{\prime} \mathrm{N}\right.$, $\left.95^{\circ} 40^{\prime} \mathrm{E} \sim 119^{\circ} 55^{\prime} \mathrm{E}\right)$ is the most important economic development region of the CMREC, which consists of Russia's Siberian Baikal region, Mongolia's "Steppe Road Program" region and China's Inner Mongolia, including the Republic of Buryatia and Irkutsk Oblast, Russia; Dornogovi, Dundgovi, Govisümber, Töv, Ulaanbaatar, Darkhan-Uul and Selenge, Mongolia, and Hohhot, Ulanqab and Xilingol in Inner Mongolia, China (Fig. 1). In 2010, China surpassed Japan to become the second largest country in terms of GDP and then reached US $\$ 11.062$ trillion in 2015, with Russia US $\$ 1.363$ trillion and Mongolia US\$0.012 trillion at the same time. China's exports in 2015 reached US $\$ 2.27$ trillion, ranking first with $13.8 \%$ of the global share. But as a developing country, GDP per capita of China was US\$8067 ( $74^{\text {th }}$ in the world), which was US $\$ 9313$ in Russia (67 $7^{\text {th }}$ in the world) and US\$3919 in Mongolia (106th in the world). Three counties were much lower than Luxembourg, the first county of GDP per capita with US\$101376. To promote continuous economic growth, China explore new forms of international economic cooperation with new partners. BRI is an initiative attempt and assert greater international influence and contribute to the international economic architecture [45].

The altitude is $150 \mathrm{~m} \sim 3500 \mathrm{~m}$, and the terrain is generally lower in the north-western Siberian Baikal region and higher on the central and southern Mongolian Plateau (Fig. 1). The majority of the study area is covered by the Mongolian Plateau, which is bounded by the Sayan and Khentii mountains to the north, the Greater Hinggan Mountains to the east, the Yin Mountains to the south, and the Altai Mountains to the west [46]. The main climate in this area is the continental climate, with a long, cold and dry winter, and most rainfall is concentrated in a warm summer [47-49]. The region is influenced by the Pacific monsoon from east to west, and solar radiation increases from north to south. Due to the various terrain, temperature and rainfall conditions, the landscapes are very different in the three nations. Forest is mostly distributed in the Siberian Baikal region and in the northern mountains of the Mongolian Plateau. Unused land (mainly consisting of bare area) is located in Dornogovi, Dundgovi and Govisümber in southern Mongolia and in part of northeastern Xilingol. Grassland dominates more than half of the landscape in Inner Mongolia and the north-western part of Mongolia (Fig. 2). In Russia, the forest cover was greater than $80 \%$ in 1992, and the other land classes had smaller proportions, as follows: $5.66 \%$ cropland, $5.47 \%$ water and $3.31 \%$ grassland. However, in Mongolia the land cover mainly consisted of $52.03 \%$ bare area, $17.24 \%$ sparse vegetation and $15.79 \%$ grassland. Inner Mongolia is the most important livestock production area in China, and grassland is the dominant land class (approximately 52.56\%), with sparse vegetation covering $22.30 \%$.
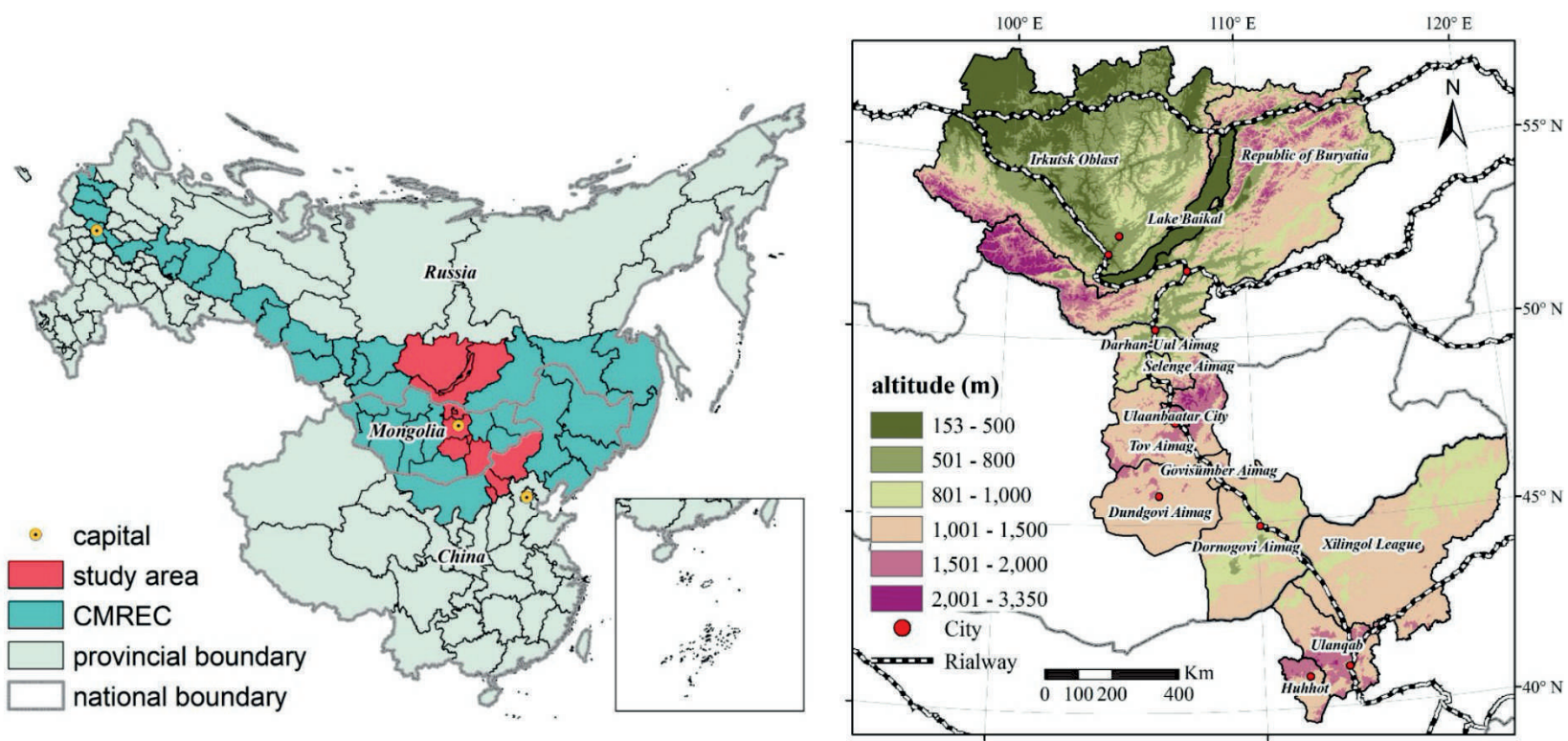

Fig. 1. The location and altitude of study area within the CMREC. 


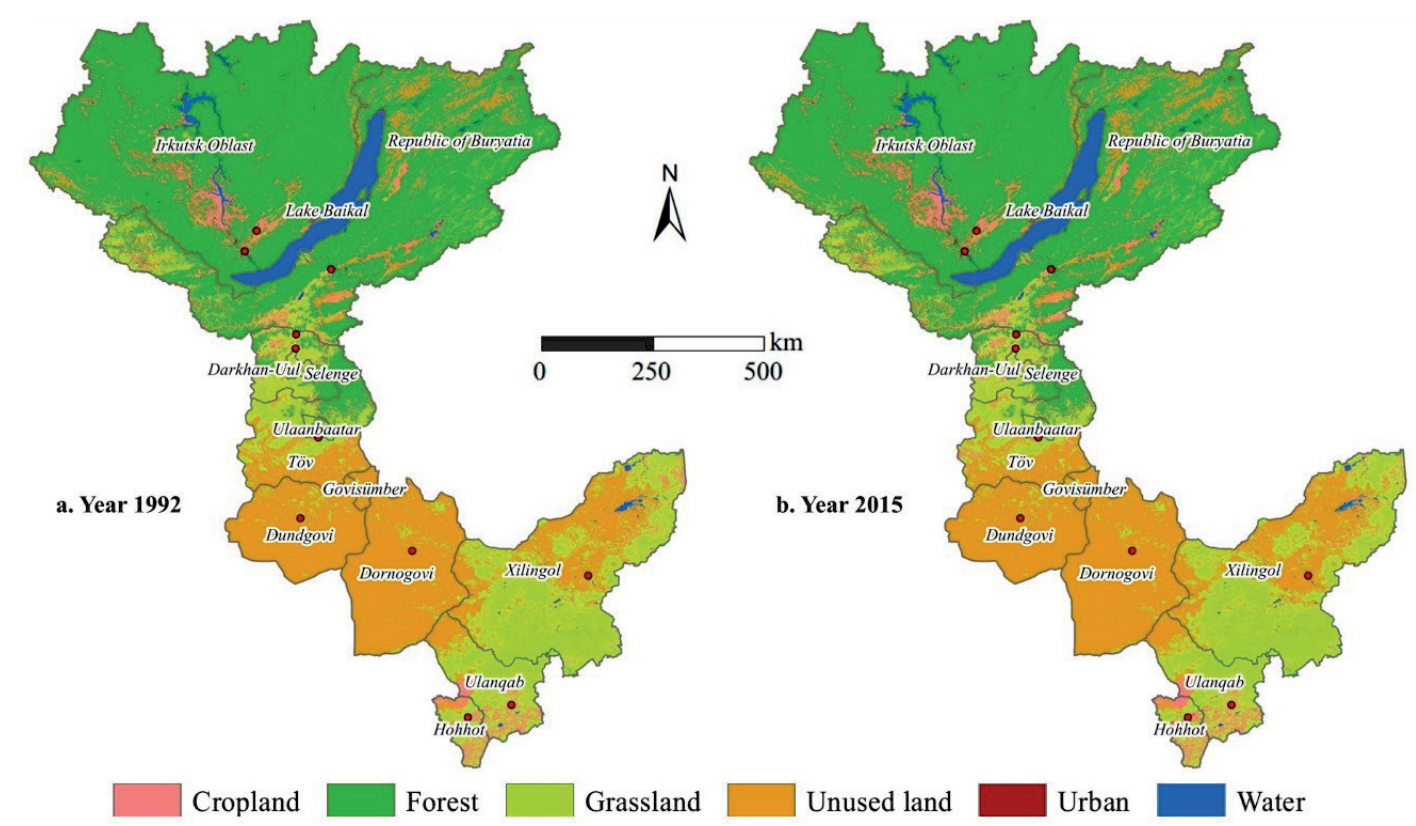

Fig. 2. Six classes of land cover in 1992 and 2015.

\section{Source and Process of Data}

The European Space Agency (ESA) Climate Change Initiative (CCI) project delivered high-quality satellitederived geophysical products, such as the Land Cover product, for the essential climate variables (ECVs) and the climate modelling community (CMC). This Land Cover dataset contains 24 consistent global land cover maps at a spatial resolution of $300 \mathrm{~m}$ on an annual basis from 1992 to 2015; it used the geographic coordinate system (GCS) based on the World Geodetic System 84 (WGS-84) reference ellipsoid. The land cover class was defined using the Land Cover Classification System (LCCS) developed by the United Nations (UN) Food and Agriculture Organization (FAO) [50, 51]. There are a total of 22 classes of land cover designed to be globally consistent, and there are 37 detailed classes at the regional level. In this study, the Land Cover dataset was used from 1992 to 2015 and was extracted for the study area. Referring to the Land Cover Product User Guide Version 2 (https://www.esa-landcover-cci. org/?q=webfm_send/84), we reclassified the original 37 land cover classes into a new land category with 6 land classes: cropland, forest, grassland, urban, water and unused land [52, 53] (Table 1).

Studies have shown that accessibility factors (e.g., distance to railway, highways, cities, water) are the most important factors related to LUCC that remould the ecosystem, society and urban spatial distributions $[54,55]$. We calculated the distance from the land cover raster data to the railway, highway and city data as the socioeconomic factors in ArcGIS 10.2 software (http://www.esri.com/). Environmental factors have a far-reaching effect on LUCC. These factors include the normalized difference vegetation index (NDVI), precipitation, temperature, altitude, slope and distance to water.

The NDVI is a popular sensitive index used for monitoring the characterization and variability of vegetation, which could be used to trace land cover vegetation dynamic changes. Due to the time span of our study, we used the GIMMS (Global Inventory Modeling and Mapping Studies) NDVI3 g dataset, which is currently the longest global sub-monthly time series available from July 1981 to December 2015 $[56,57]$. The GIMMS NDVI3 g dataset is the 16-day MVC (maximum value composite procedure) with a spatial resolution of $8 \mathrm{~km}$, derived from the AVHRR (Advanced Very High Resolution Radiometer) instrument on-board NOAA (National Oceanic and Atmospheric Administration) satellites [58]. To analyse the NDVI change between years, we calculated the MVC in each year using MATLAB 2016a. Therefore, we had the yearly maximum NDVI values from 1982 to 2015 .

In addition, the digital elevation model (DEM; $90 \mathrm{~m} \times 90 \mathrm{~m}$ ) data were used to obtain the altitude from the NASA Shuttle Radar Topographic Mission (SRTM, http://srtm.csi.cgiar.org/). Precipitation and temperature were provided by the National Centers for Environmental Prediction (NCEP, http://rda.ucar. edu/). Precipitation was added from the monthly mean (1 per day) of 6-hour accumulation data with a spatial resolution of $0.5^{\circ} \times 0.5^{\circ}$. The temperature was the monthly mean ( 1 per day) of 6-hour forecasts with a spatial resolution of $0.312^{\circ} \times 0.312^{\circ}$ from 1992 to 2010 and $0.205^{\circ} \times 0.205^{\circ}$ from 2011 to 2015 . To unify the raster size, we resampled the temperature data before 2010 to a resolution of $0.205^{\circ} \times 0.205^{\circ}$. The accumulated precipitation and average temperature were both processed in MATLAB 2016a. 
Table 1. Relationships between our new land categories and the LCCS legend in the ESA.

\begin{tabular}{|c|c|}
\hline Land cover class & LCCS legend and its code number used in ESA \\
\hline \multirow{4}{*}{ Cropland } & Rainfed cropland \\
\hline & Irrigated cropland \\
\hline & Mosaic cropland $(>50 \%)$ /natural vegetation (tree, shrub, herbaceous cover) $(<50 \%)$ \\
\hline & Mosaic natural vegetation (tree, shrub, herbaceous cover) $(>50 \%) /$ cropland $(<50 \%)$ \\
\hline \multirow{8}{*}{ Forest } & Tree cover, broadleaved, evergreen, closed to open $(>15 \%)$ \\
\hline & Tree cover, broadleaved, deciduous, closed to open $(>15 \%)$ \\
\hline & Tree cover, needle-leaved, evergreen, closed to open $(>15 \%)$ \\
\hline & Tree cover, needle-leaved, deciduous, closed to open $(>15 \%)$ \\
\hline & Tree cover, mixed leaf class (broadleaved and needle-leaved) \\
\hline & Mosaic tree and shrub $(>50 \%) /$ herbaceous cover $(<50 \%)$ \\
\hline & Tree cover, flooded, fresh or brackish water \\
\hline & Tree cover, flooded, saline water \\
\hline \multirow{2}{*}{ Grassland } & Mosaic herbaceous cover $(>50 \%) /$ tree and shrub $(<50 \%)$ \\
\hline & Grassland \\
\hline Urban & Urban area \\
\hline \multirow{2}{*}{ Water } & Water \\
\hline & Shrub or herbaceous cover, flooded, fresh-saline or brackish water \\
\hline \multirow{5}{*}{ Unused land } & Shrubland \\
\hline & Lichens and mosses \\
\hline & Sparse vegetation (tree, shrub, herbaceous cover) \\
\hline & Bare areas \\
\hline & Permanent snow and ice \\
\hline
\end{tabular}

\section{LUCC Change Rate}

To measure the speed of the LUCC in the study period, we calculated the change rate as follows:

$$
A_{i \text {-rate }}=\frac{A_{i \text {-end }}-A_{i \text {-start }}}{A_{i \text {-start }}} \times \frac{1}{\mathrm{~T}} \times 100 \%
$$

Here, $A_{i-r a t e}$ is the change rate of land class $i$ in study period $T$, and $A_{i \text {-end }}$ and $A_{i \text {-start }}$ are the areas of land class $i$ at the end and at the start of the study period, respectively [14, 59].

\section{LUCC Transfer Matrix}

To clearly describe the different land class changes, we used the transfer matrix to calculate the detailed land change information $[17,60]$. The matrix is expressed as:

$$
A_{i j}=\left[\begin{array}{ccc}
A_{11} & \ldots & A_{1 n} \\
\vdots & \ddots & \vdots \\
A_{n 1} & \cdots & A_{n n}
\end{array}\right]
$$

In the formula, $A_{i j}$ is the land class change area from class $i$ to class $j, i$ is the land class at time $t, j$ is the land class at time $t+1$, and $n$ is the total number of land classes. Each row $\left(A_{i 1} \ldots A_{i n}\right)$ reflects the detailed area change from class $i$ to class $1 \ldots n$. Each column $\left(A_{1 j} \ldots A_{n j}\right)$ reflects the detailed area change from class $1 . . . n$ to class $j$.

\section{Landscape Vulnerability Change}

Landscape vulnerability denotes the probability that a class of land cover transitions from the current steady state after experiencing an external interference. These results could indicate the anti-interference ability of the ecosystem to human activity. An ecosystem with more complicated land cover could be able to buffer interference from humans and have strong robustness and stability. Here, we define the vulnerability grade for a specific land cover as $V$. According to the characteristics of the study area, we referred to previous study results (e.g., [22, 23, 61]) and ranked the land cover vulnerability into 6 grades: $V_{\text {urban }}=1, V_{\text {forest }}=2$, $V_{\text {grassland }}=3, V_{\text {cropland }}=4, V_{\text {water }}=5$ and $V_{\text {unusedland }}=6$. 
In this study, we focus on the absolute changes in vulnerability. If urban land $\left(V_{u r b a n}=1\right)$ changes into unused land $\left(V_{\text {unusedland }}=6\right)$, the land cover vulnerability change is " -5 ", which is the same as the change result of "5" from unused land $\left(V_{\text {unusedland }}=6\right)$ to urban land $\left(V_{\text {urban }}=1\right)$. Therefore, we used the absolute value of Formula (3) to assess the land cover vulnerability change:

$$
\begin{gathered}
V_{i}^{t \rightarrow t+1}=\operatorname{abs}\left(V_{i}^{t}-V_{i}^{t+1}\right) \\
V_{i}^{t \rightarrow t+1}=\left\{\begin{array}{l}
1,2,3,4,5 \text { (changed) } \\
0 \quad \text { (unchanged) }
\end{array}\right.
\end{gathered}
$$

...where $V_{i}^{t}$ is the value of the vulnerability grade of pixel $i$ at year $t ; V_{i}^{t+1}$ is the value of the vulnerability grade at year $t+1$; and $V_{i}^{t \rightarrow t+1}$ is the absolute value of the vulnerability change grade of pixel $i$ from year $t$ to year $t+1$. As there are 6 relative vulnerability grades, and the change results $V_{i}^{t \rightarrow t^{+}}$range from 1 to 5, a value of 0 represents unchanged land cover vulnerability (Formula (4)).

\section{Spatial Gravity Model of Land Cover Vulnerability Change}

To identify the centre of vulnerability, the spatial gravity model $[26,62]$ was updated as the following formula:

$$
\begin{aligned}
& X^{t \rightarrow t+1}=\frac{\sum_{i=1}^{n} V_{i}^{t \rightarrow t+1} \times x_{i}}{\sum_{i=1}^{n} V_{i}^{t \rightarrow t+1}} \\
& Y^{t \rightarrow t+1}=\frac{\sum_{i=1}^{n} V_{i}^{t \rightarrow t+1} \times y_{i}}{\sum_{i=1}^{n} V_{i}^{t \rightarrow t+1}}
\end{aligned}
$$

...where $X_{i}^{t \rightarrow t+1}$ and $Y_{i}^{t \rightarrow t+1}$ represent the longitude and latitude coordinates of the vulnerability gravity centre from year $t$ to $t+1$, respectively; $x_{i}$ and $y_{i}$ represent the longitude and latitude coordinates of pixel $i$, respectively; and $V_{i}^{t \rightarrow t+1}$ is used as the weight coefficient. Therefore, the coordinates of the vulnerability change centre are the weighted and summed results, which could represent the location of the most vulnerable place under the effect of environmental and socioeconomic activities.

We assigned a vulnerability grade to each land cover grid. Then, we compared two successive vulnerability grade maps to obtain $V_{i}^{t \rightarrow t+1}$, and we retained only the changed grids. After that, we used Formula 5 to obtain the central vulnerability positions of land cover for China, Mongolia and Russia. All spatial processes were processed with ArcGIS 10.2 using the "raster calculation", "mean center" and "zonal statistics" tools in ArcToolbox.

\section{Random Forest}

$\mathrm{RF}$ is an ensemble tree-structured classifier, $\{h(x, \Theta, k=1, \ldots)\}$, where the $\left\{\Theta_{k}\right\}$ values are identical independently distributed random vectors, and $x$ is an input vector of each tree used to vote for the most popular class [29]. Each node is split when the randomly chosen predictor is the best at that node. This strategy proves to perform better than many other classifiers, including discriminant analysis, support vector machines and neural networks, and the method is robust against overfitting. Furthermore, RF is very user friendly because it is usually not very sensitive to their values and has only two parameters: the number of variables for splitting at each node in the random subset $\left(m_{\text {try }}\right)$ and the number of trees in the forest $\left(n_{\text {tree }}\right)$ $[63,64] . m_{t r y}$ controls the size of each tree, and $n_{\text {tree }}$ determines the number of trees in the RF. The default values of $m_{t r y}$ (using the integer value) are the square root of the number of variables used for classification [31]. To obtain the best classification results, we used $m_{t r y}=1,2 \times \times \times(k-1)$, where $\mathrm{k}$ is the number of variables. For $n_{\text {tree }}$, the default value is 500 , and $m_{\text {tree }}=50$ is adequate in most applications [30]. We used $m_{\text {tree }}=10$, $50,100,500$ to obtain the best resuThe error estimate is called "out-of-bag" (OOB), and it is an intensely unbiased estimate of the generalization error [33]. To assess the variable importance, RF alters one random input variables at a time, while keeping the other variables constant. It estimates the decreased accuracy of the mean OOB error as the variable importance indicator for each replaced variable [29]. To evaluate the results of RF, we used the confusion matrices to calculate the producer's accuracy (PA) and user's accuracy (UA) for each class and the overall accuracy for the total correct classification rate and Cohen's kappa coefficient [65]. We compared the two vulnerability grade maps of 1992 and 2015 and assigned $V_{i}^{t \rightarrow t+1}$ to each changed grid. The socioeconomic and environmental factors are the independent factors, and $V_{i}^{t \rightarrow t+1}$ is the dependent factor in RF. In this study, we used the randomForest package in R 3.6.1 to perform RF analysis.

\section{Results and Discussion}

\section{Temporal Pattern of LUCC}

From 1992 to 2015, LUCC fluctuated in two opposite directions, and overall the ecological environment deteriorated in the CMREC. Cropland, grassland, urban areas and unused land had an increasing tendency, and urban areas showed a stable increase the entire time from $1996.65 \mathrm{~km}^{2}$ to $3543.75 \mathrm{~km}^{2}$. In contrast, forests and water decreased. Since 1992, forest was the largest land cover in the study area with $1.04 \times 10^{6} \mathrm{~km}^{2}$, and then it decreased by $21,116.7 \mathrm{~km}^{2}$ until 2015 . The land cover area of cropland, grassland, unused land and forest stabilized in approximately 2003. In contrast, water fell sharply, by $764.73 \mathrm{~km}^{2}$, from 2000 to 2005 (Fig. 3).

For 23 years, the order of the overall change rate was as follows: urban $(3.37 \%)>$ cropland $(0.35 \%)>$ forest 

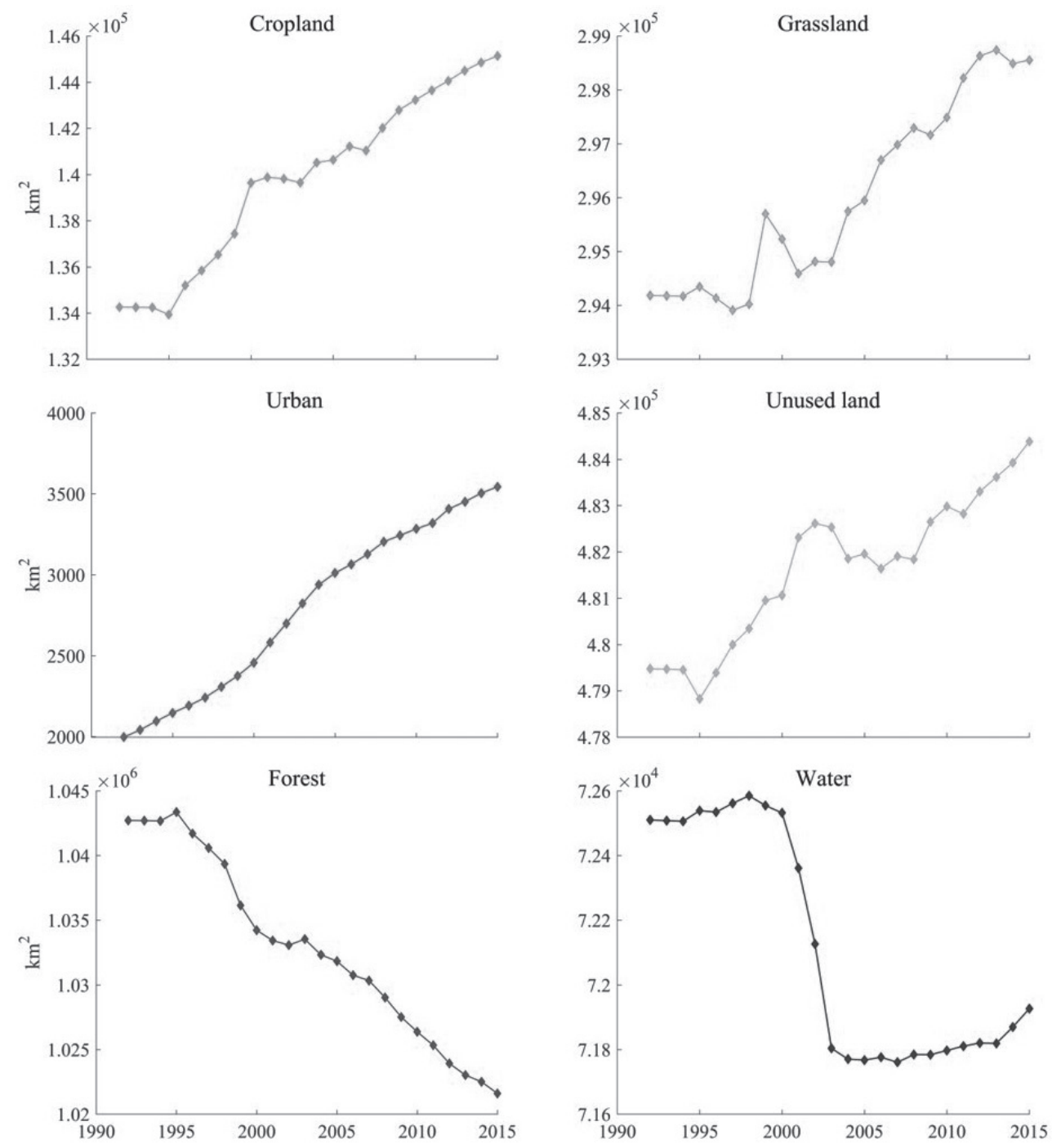

Fig. 3. Six classes of LUCC from 1992 to 2015.

$(-0.09 \%)>$ grassland $(0.06 \%)>$ unused land $(0.04 \%)>$ water $(-0.04 \%)$ (Fig. 4). After 1995, the rate of cropland and unused land shifted from negative to positive and then continued to increase; in contrast, forest showed an opposite trend. Both grassland and urban areas were always increasing, and urban areas had the highest rate of $4.51 \%$ between 2000 and 2005 . Meanwhile, water had the largest decreasing rate of $-0.21 \%$.

When separately comparing the three nations, China had the highest speed of urbanization and experienced

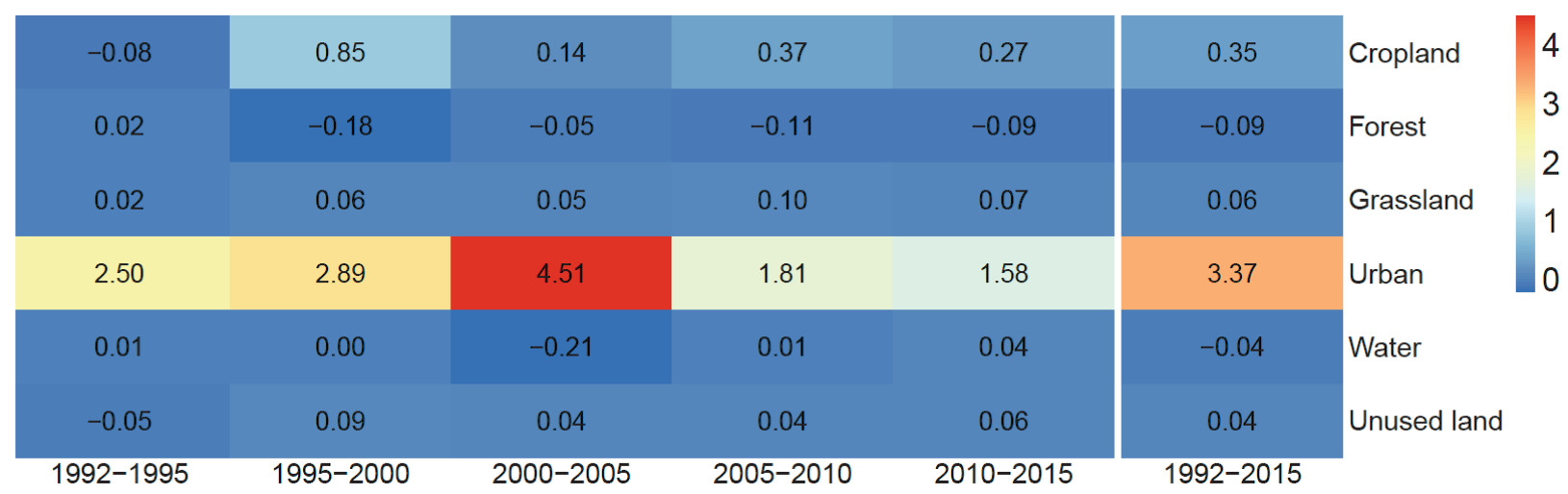

Fig. 4. Heat map of area change rate in study area (\%). 


\section{China}

\begin{tabular}{|c|c|c|c|c|c|c|}
\hline-0.21 & 0.20 & -0.24 & -0.15 & -0.11 & -0.09 & Cropland \\
\hline 0.00 & 0.16 & 0.48 & 0.37 & 0.12 & 0.25 & Forest \\
\hline 0.01 & -0.02 & 0.10 & 0.07 & 0.04 & 0.04 & Grassland \\
\hline 2.25 & 1.78 & 28.88 & 10.27 & 5.70 & 19.68 & Urban \\
\hline-0.20 & -0.26 & -0.70 & 0.04 & 0.12 & -0.20 & Water \\
\hline 0.03 & -0.20 & -0.50 & 0.44 & 0.05 & -0.05 & Unused land \\
\hline $92-1995$ & $1995-2000$ & $2000-2005$ & $2005-2010$ & 2010-2015 & $992-20$ & \\
\hline
\end{tabular}

Russia

\begin{tabular}{|c|c|c|c|c|c|l}
\hline 0.05 & 0.94 & 0.18 & 0.71 & 0.55 & 0.54 & $\begin{array}{l}3 \\
2.5\end{array}$ \\
2 \\
0.02 & -0.17 & -0.04 & -0.10 & -0.09 & -0.09 & Forest \\
1.5 \\
0.01
\end{tabular}

\section{Mongolia}

\begin{tabular}{|c|c|c|c|c|c|c|}
\hline-0.21 & 2.02 & 0.75 & 0.24 & 0.09 & 0.67 & Cropland \\
\hline 0.04 & -0.31 & -0.20 & -0.18 & -0.12 & -0.17 & Forest \\
\hline 0.05 & -0.13 & -0.11 & 0.18 & 0.12 & 0.02 & Grassland \\
\hline 1.34 & 0.81 & 11.86 & 0.95 & 2.19 & 4.36 & Urban \\
\hline-0.03 & -0.05 & 0.06 & 0.02 & -0.02 & 0.00 & Water \\
\hline-0.04 & -0.18 & -0.25 & 0.02 & 0.06 & -0.08 & Unused land \\
\hline 1992-1995 & $1995-2000$ & $2000-2005$ & $2005-2010$ & 2010-2015 & $1992-2015$ & \\
\hline
\end{tabular}

Fig. 5. Heat map of area change rate of China, Mongolia and Russia.

the most forest revegetation. From 2000 to 2005, China experienced the fastest urbanization, reaching $28.88 \%$, and Mongolia experienced an increase of $11.86 \%$, which was higher than Russia, which had a value of $2.22 \%$. Then, urbanization slowed, and China, Mongolia and Russia experienced decreased to 5.7\%, $2.19 \%$ and $0.47 \%$, respectively. Furthermore, in contrast to Mongolia and Russia, China was increasing its vegetation. The area of forest increased at an average speed of $0.25 \%$ in China, which was opposite to the decreasing rates of $-0.09 \%$ in Russia and $-0.17 \%$ in Mongolia. Moreover, although cropland and unused land decreased in China, the overall rates were $-0.09 \%$ and $-0.05 \%$, respectively. Russia rapidly expanded cropland at a rate of $0.54 \%$ and unused land of $0.34 \%$. Mongolia also had an increasing rate of $0.67 \%$ of cropland, while deduced the unused land at a rate of $-0.08 \%$. For grassland, all three nations experienced increase, and the maximum average rate was $0.25 \%$ in Russia, $0.04 \%$ in China and $0.02 \%$ in Mongolia. Water decreased by $-0.2 \%$ and $-0.03 \%$ in China and Russia, respectively (Fig. 5).

The detailed LUCC information for each land class is shown in Table 2. Each row represents the transfer of one class to the other classes from 1992 to 2015. The areas of cropland transferred into forest and grassland were $3546 \mathrm{~km}^{2}$ and $3103 \mathrm{~km}^{2}$, respectively. Most of the area of water was transferred into forest, with a value 
Table 2. LUCC transfer matrix from 1992 to $2015\left(\mathrm{~km}^{2}\right)$.

\begin{tabular}{|c|c|c|c|c|c|c|}
\hline 1992 & Cropland & Forest & Grassland & Urban & Water & Unused land \\
\hline Cropland & 126499 & 3546 & 3103 & 395 & 12 & 707 \\
\hline Forest & 9869 & 1011874 & 6303 & 400 & 545 & 13725 \\
\hline Grassland & 3748 & 2179 & 281868 & 481 & 12 & 5896 \\
\hline Urban & 0 & 0 & 0 & 1997 & 0 & 0 \\
\hline Water & 132 & 798 & 43 & 22 & 71320 & 194 \\
\hline Unused land & 4887 & 3202 & 7236 & 250 & 37 & 463871 \\
\hline
\end{tabular}

of approximately $798 \mathrm{~km}^{2}$. In addition, $7236 \mathrm{~km}^{2}$ of unused land changed to grassland. In each column, the value also represented the area of one class that changed into the other classes. Forest was the largest source of unused land, contributing approximately 13,725 km². Urban areas were only increasing and encroaching on other land classes.

\section{Spatial Patterns of Vulnerability Gravity Centre}

Fig. 6 shows the 23-year movement of the vulnerability gravity centres of LUCC in China, Russia and Mongolia. The overall distribution of vulnerability gravity centres was more dispersive, and the direction showed a northeast-southwest pattern in China. Centres

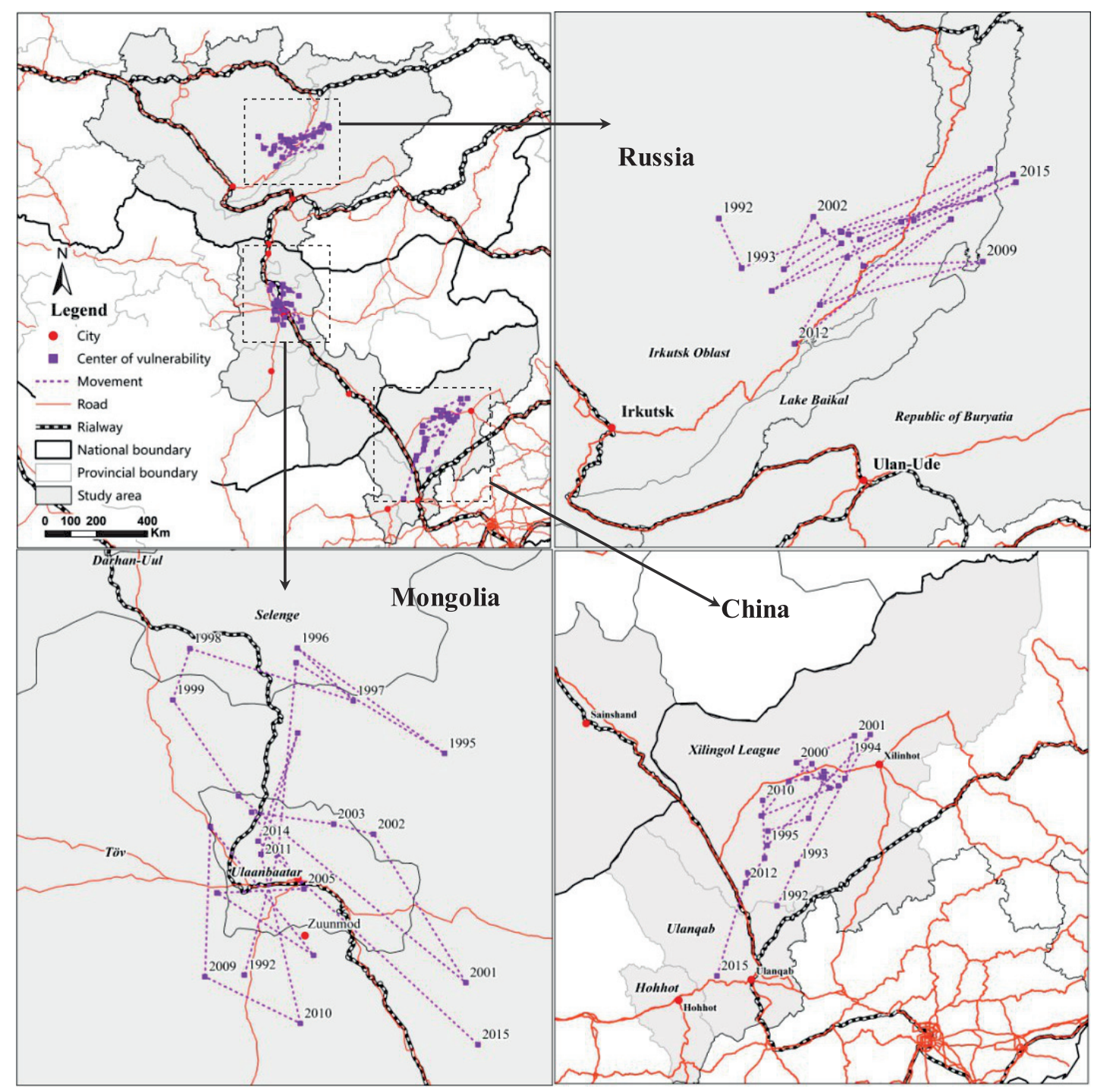

Fig. 6. Spatial vulnerability gravity centres of LUCC in China, Russia and Mongolia from 1992 to 2015. 
Table 3. Confusion matrices for RF classification of LUCC vulnerability grade.

\begin{tabular}{|c|c|c|c|c|c|c|c|}
\hline Grades & $\mathbf{1}$ & $\mathbf{2}$ & $\mathbf{3}$ & $\mathbf{4}$ & $\mathbf{5}$ & Total & UA (\%) \\
\hline $\mathbf{1}$ & 150410 & 20815 & 979 & 6520 & 258 & 178982 & 84.04 \\
\hline $\mathbf{2}$ & 18506 & 192428 & 1241 & 4747 & 247 & 217169 & 88.61 \\
\hline $\mathbf{3}$ & 1032 & 1716 & 161569 & 730 & 174 & 165221 & 97.79 \\
\hline $\mathbf{4}$ & 3770 & 3958 & 276 & 180282 & 50 & 188336 & 95.72 \\
\hline $\mathbf{5}$ & 391 & 364 & 233 & 98 & 1690 & 2776 & 60.88 \\
\hline Total & 174109 & 219281 & 164298 & 192377 & 2419 & 752484 & \\
\hline PA (\%) & 86.39 & 87.75 & 98.34 & 93.71 & 69.86 & & \\
\hline Overall accuracy & & & & & & & \\
\hline Kappa & & & & & & & \\
\hline
\end{tabular}

moved from the central region (1992) to north-eastern Xilingol League (1994-2014) and back to Ulanqab (2015). In Mongolia, the vulnerability gravity centres were concentrated around Ulaanbaatar, within Selenge Aimag and Tov Aimag, and this pattern was closely distributed along the Mongolian "Prairie Road". For Russia, the vulnerability centres were distributed on both sides of Lake Baikal, moving from Irkutsk Oblast (1992) to the nearshore regions of Lake Baikal, and that distribution was symmetrical along the highway.

\section{Relative Importance of Driving Factors}

The confusion matrix summarizes the RF results to classify the 5 vulnerability grades of LUCC (Table 3). The overall accuracy was $91.22 \%$, and the kappa coefficient was $88.27 \%$, which was sufficient to analyse and predict the driving factors. The UA ranged from $60.88 \%$ (grade 5) to $97.79 \%$ (grade 3 ), and the PA ranged from $69.86 \%$ to $98.34 \%$.

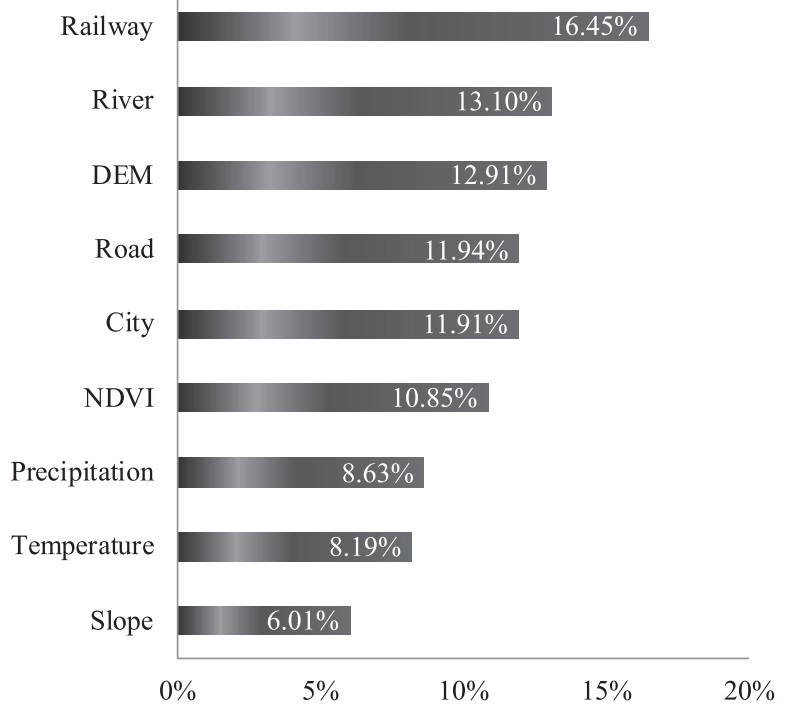

Fig. 7. Variable relative importance for RF classification model.
To determine the relative importance and rank of the factors, we used the mean decreased accuracy of the OOB error (Fig. 7). Overall, railway was the most important factor, accounting for nearly $16.45 \%$. The accumulated value of the top 5 factors (railway $16.45 \%>$ river $13.10 \%>$ altitude $12.19 \%>$ highway $11.94 \%$ $>$ city $11.91 \%$ ) was greater than $66 \%$, and socioeconomic factors (e.g., railway, highway and city) were more important than the environmental factors (e.g., river and altitude).

\section{Discussion}

It is challenging to identify the spatiotemporal patterns of multiple land classes and quantitatively analyse the driving factors of LUCC. Our study mainly focused on 6 land classes along the CMREC from 1992 to 2015. We defined the land cover vulnerability grade $(V)$ and then calculated the absolute vulnerability grade change $\left(V_{i}^{t \rightarrow t+1}\right)$ for each land cover class. Using a spatial gravity model with $V_{i}^{t \rightarrow t+1}$ as the weight coefficient, we measured the spatial movement of the vulnerability gravity centres. To determine the relative importance of the socioeconomic and environmental driving factors, machine learning (i.e., RF) was used as an effective method to address many factors in a large area and over a long period. This research compared the LUCC patterns of three counties to better understand their different environments, policies and cultures.

Our findings are consistent with LUCC studies in the CMREC. In Inner Mongolia, Yin et al. [66] found that the forest area clearly increased between 2001 and 2014; cropland accounted for $0.29 \%$ of the forest gain area; the decreasing rate of cropland peaked in 2003 and then slowed. Li et al. [67] proved that grassland production increased slightly in Mongolia along the railway line from 2006 to 2015, which conformed to the increased area rates of $0.18 \%(2006-2010)$ and $0.12 \%(2010-2015)$. From 2005 to 2015, the typical city of Irkutsk showed that the annual changes in land use were dramatic from 2005 to 2010 and then slowed. Moreover, rapid urban 
expansion caused forest, grassland and bare land to continuously decrease [17].

Socioeconomic factors played a more important role than did environmental factors. Infrastructure and its impacts are key drivers of biodiversity loss. CMREC will cross several terrestrial vulnerable conservation areas, such as National Parks and Nature Reserves of Baikal. This disruptions will create obvious threats to biodiversity. Roads, for example, open a Pandora's box of environmental impacts, such as habitat loss, fragmentation, invasive species, and illegal activities such as poaching and logging [68]. Li discussed the environmental factors and socioeconomic factors of LUCC in the western bank of Lake Baikal, Irkutsk. The results showed that human activities had the greatest effect on land degradation, and climate change had the second highest impact [17]. In Zambia, longterm land cover change showed that the major factors of LUCC were agricultural area, distance to water bodies, change in crop yield, mean temperature and altitude [55].

The spatial patterns of vulnerability gravity centres reflected socioeconomic distribution and transition. Urbanization was the direct process causing the transition from natural landscape to human artificial landscape [69]. Mongolia has a highly concentrated population and economics in the capital city of Ulaanbaatar. It was the largest city, with a $0.46 \%$ ratio of the population in Mongolia and a $0.65 \%$ proportion of the GDP in 2015 [70]. However, the ratios of population and GDP were $1.8 \%$ and $2.6 \%$, respectively, from Inner Mongolia to China, 1.6\% and $1.5 \%$, respectively, from Irkutsk Oblast to Russia and $0.7 \%$ and $0.3 \%$ from the Republic of Buryatia to Russia. Population and economic agglomerations caused intensive human activity levels that would substantially change land cover. Therefore, the spatial pattern of vulnerability gravity centres was closely centred around Ulaanbaatar, while those of China and Russia were more dispersed and showed greater changes.LUCC tended to occur along the railways, highways and rivers that were adjacent to the vulnerability gravity centres (Fig. 7). Undoubtedly, roads are the bridge or engine for economic development. The Baikal region has always been one of the most important forest management and timber production regions in Russia. This is because the Trans-Siberian Railway conveniently transports timber and increased timber production 1.7-fold higher in Irkutsk Oblast than the average of the Russian Federation [71]. From Zamiin-Uud to Sukhbaatar, the railway crossed through the most important transportation line and boosted Mongolian logistics and transportation. Currently, the BRI proposed to build transportation networks with Mongolia's "Steppe Road Program" and Russia's "Eurasian Economic Union". The programs dovetail neatly with each other and could contribute to the development efforts of three nations, which is especially beneficial for landlocked Mongolia. Moreover, LUCC is more likely near rivers, which is an indispensable factor of social production. Ulaanbaatar is located along the Tuul River Valley, where buildings were distributed nearly $24 \mathrm{~km}$ in the east-west direction [69].

Human activity, especially national-level policy, had a direct and even far-reaching impact on LUCC. Since 2000, the Chinese government has launched a series of the world's largest government-financed payment to ecosystem services programs, aiming to regain forest and grassland and relieve human activity pressure on ecosystems [72]. Faced with severe land degradation, Inner Mongolia is the core protection area with the highest national investment in environmental restoration programs in China $[66,73]$. The Environmental Forest Conservation Program (NFCP) and Returning Cropland to Forest and Grassland Project started in 2000, which intended to reduce the deforestation and convert cropland into forest and grassland [74]. Moreover, to relieve the sandstorm influence on the BeijingTianjin metropolitan area, the Beijing and Tianjin Sandstorm Source Treatment Project (BTSST) Phase I also launched and revegetated cropland areas in 2001 [75]. Three national-level ecological programs were conducted in Hohhot, Ulanqab and Xilingol League. Fig. 5 clearly shows the dramatic changes in the forest, grassland and cropland before and after 2000. The rapid forest gain before 2004 is in accordance with the investments made in the early stages of the ecological programs [76]. However, as grain production has been diminished at the expense of forest expansion, the policy goal to increase forest cover was reduced after 2003, which led to lower increasing rates of forest cover after 2003 [66, 77].

Mongolia has a traditional nomadic pastoral culture in which herders move their livestock between winter and spring to effectively utilize pastures and avoid livestock overgrazing. After 1992, Mongolia liberated the economy and implemented the privatization of livestock and land use [78, 79]. Herders altered their seasonal patterns of pastoral land use and preferred to increase livestock production. However, more frequent movements broke the equilibrium of the ecosystem, and overgrazing caused severe land degradation [80]. The highly degraded area increased by 1.8 times after 1995 [81], and desertification increased by 3.4\% from 1990-2004 [82]. In 2005, the Mongolian government changed polices to modify the administrative-territorial division, which allowed herders to get a larger region for seasonal nomadism and a better sustained pasture ecosystem [80]. After these policies were implemented, Mongolia showed a dramatic change in grassland, which decreased from 1995 to 2005 after land privatization and suddenly increased as the new policy was launched.

After the Soviet Union dissolved in 1990, the Russian forest industry abruptly reduced production within a few years [47]. Since the new legislation enacted in 1993-1994 was implemented, sustainable forest management has been adopted. However, more control of forest management was given to regional 
authorities [83, 84], and national legislation met the challenge of local development management. The policy-led land areas changed rapidly during 1995-2000. The change rates of cropland, forest, grassland, urban areas and unused land were highest, such as that of grassland, with a value of $0.73 \%$; however, these rates were $0.07 \%$ during 2000-2005 (Fig. 5).

BRI is a call for an open and inclusive (mutually beneficial) model of cooperative economic, political and cultural exchange. The CMREC is an important measure to respond to the challenges of economic globalization and to meet the development requirements of regional economic integration. It integrates the three countries' interest, laying the infrastructural and industrial foundations to secure and solidify relations and to modernize and reduce the poverty. Besides, it also radiate the Northeast Asian regions and grow symbiotic relationship between the European and Asian markets. The formation of the Eurasian Economic Belt will also produce a win-win situation and promote the arrival of the new Asia-Europe century era.

Environmental issues threat the plan of CMREC, but also bring opportunities. Facing the challenges of environmental protection is indispensable for the sustainable development of the economy. Infrastructure (especially road and railway) and national boundary disrupt ecological process; interrupt animal migration corridor, lead to an isolated wildlife habitat, and strongly contribute to the fragmentation of the landscape $[85$, 86]. A poor planned infrastructure has the risk of bring undesirable environmental practices in the future. Conversely, it is also an opportunity for decisionmakers, infrastructure planners and conservationists, that they try to work together to mitigate human activity negative impacts [68]. A network of protected areas and wildlife corridors across Eurasia is important to mitigate the infrastructure influence on biodiversity. Therefore, strengthening cooperation in the ecological environment is also the focus of the CMREC.

To better understand the dynamic of the LUCC under changing conditions, further work is needed to integrate more detailed information on the feedbacks between LUCC and human society development, in addition to more accurate socioeconomic and policy data that reflect the social and political context. Simulation models provide promising tools for large-scale research, but they should rely on empirical fields studies at local scales. We need to take more experiments to identify our critical factors thresholds. LUCC in the future should be considered in climate change projections and make scientific predictions over CMREC to improve the accuracy of the assessment.

\section{Conclusions}

The findings from this study clarified the spatiotemporal patterns of LUCC in the CMREC from
1992 to 2015, and we identified the spatial transition of the vulnerability gravity centres and the values of the environmental and socioeconomic driving factors. In summary, (1) the ecological environment deteriorated in the CMREC with the increasing area of cropland, unused land, urban areas and grassland, while the area of forest and water decreased. (2) From 1992 to 2015, the overall order of the change rate was as follows: urban $(3.37 \%)>$ cropland $\quad(0.35 \%)>$ forest $\quad(-0.09 \%)>$ grassland $(0.06 \%)>$ unused land $(0.04 \%)>$ water $(-0.04 \%)$. China had the highest speed of urbanization $(19.68 \%)$ and experienced the most forest revegetation $(0.25 \%)$. (3) LUCC tended to occur along the railways, highways and rivers that were adjacent to vulnerability gravity centres. The distribution of vulnerability gravity centres was dispersed and showed a northeast-southwest moving pattern in China; they were mainly concentrated around Ulaanbaatar, closely distributed along the "Prairie Road" in Mongolia, and symmetrically distributed on both sides of Lake Baikal in Russia. (4) Overall, the relative importance of the socioeconomic factors was higher than that of the environmental factors. Railway was the most important factor, and the accumulated value of the top 5 factors (railway, river, altitude, highway and city) was over $66 \%$. (5) Human activity, especially national-level policy, had a direct and even far-reaching impact on LUCC. The Chinese government successfully launched a series of the world's largest ecosystem services programs (NFCP, RCFGP and BTSST), which played an important role in improving the ecological environment.

Consequently, the following recommendations can be given: (1) the challenges of environmental protection is the primary issues for the sustainable development of CMREC. It is also an opportunity for decision-makers, infrastructure planners and conservationists, that they try to work together to mitigate human activity negative impacts. It will be a significant practices for building network of protected areas and wildlife corridors across nations, especially important for Europe with so many counties. (2) China has prompted creation of the world's largest government-financed payment for ecosystem restoration. The national conservation policies contributed significantly to restore forest and grassland, while improving livelihood options and alleviating poverty [87]. There are some valuable experiences of manage desertification and vegetation restoration, which can be adapted by Mongolia and Russia. Environment protection must be pushed ultimately by government at national level. To mitigate climate and environment change, the multinational and multilateral cooperation is a win-win way for all the counties.

In the future, with the constant promotion of the BRI, human activity will put more pressure on the ecosystem and accelerate the LUCC in the CMREC. China, Mongolia and Russia must be aligned with the common interests to protect the environment. This research will help address the challenge of sustainable socioeconomic development in a more complicated 
international environment and advise decision makers to adopt more targeted measures.

\section{Acknowledgements}

This paper was supported by the National Key Research and Development Program of China (No. 2017FY101304, 2017FY101303), the Strategic Priority Research Program (A) of the Chinese Academy of Sciences (Grant No. XDA20030203) and the National Social Science Fund of China (No. 17 VDL016).

\section{Conflicts of Interest}

The authors declare no conflict of interest.

\section{References}

1. FOLEY J.A., DEFRIES R., ASNER G.P., BARFORD C., BONAN G., CARPENTER S.R., CHAPIN F.S., COE M.T., DAILY G.C., GIBBS H.K. Global consequences of land use. Science, 309 (5734), 570, 2005.

2. IPCC. 2006 IPCC Guidelines for National Greenhouse Gas Inventories; Intergovernmental Panel on Climate Change: Geneva, Switzerland, 2006.

3. GRIMM N.B., FAETH S.H., GOLUBIEWSKI N.E., REDMAN C.L., WU J., BAI X., BRIGGS J.M. Global change and the ecology of cities. science, 319 (5864), 756, 2008.

4. LAMBIN E.F., TURNER B.L., GEIST H.J., AGBOLA S.B., ANGELSEN A., BRUCE J.W., COOMES O.T., DIRZO R., FISCHER G., FOLKE C., GEORGE P.S., HOMEWOOD K., IMBERNON J., LEEMANS R., LI X., MORAN E.F., MORTIMORE M., RAMAKRISHNAN P.S., RICHARDS J.F., SKÅNES H., STEFFEN W., STONE G.D., SVEDIN U., VELDKAMP T.A., VOGEL C., XU J. The causes of land-use and land-cover change: moving beyond the myths. Glob. Environ. Change, 11 (4), 261, 2001.

5. KASPERSON J.X., KASPERSON R.E., TURNER B.L. Regions at Risk: Comparisons of Threatened Environments; United Nations University Press: Tokyo, 1995.

6. QUINTERO-GALLEGO M.E., QUINTERO-ANGEL M., VILA-ORTEGA J.J. Exploring land use/land cover change and drivers in Andean mountains in Colombia: a case in rural Quindío. Sci. Total Environ., 634, 1288, 2018.

7. VITOUSEK P.M., MOONEY H.A., LUBCHENCO J., MELILLO J.M. Human domination of earth's ecosystems. Science, 277 (5325), 494, 1997.

8. TOLBA M.K., EL-KHOLY O.A., HOLDGATE M.W. The World Environment 1972-1992: Two Decades of Challenge; Springer Science \& Business Media: Berlin, Germany, 1992.

9. LI J., WANG Z., LAI C., WU X., ZENG Z., CHEN X., LIAN Y. Response of net primary production to land use and land cover change in mainland China since the late 1980s. Sci. Total Environ., 639, 237, 2018.

10. PEDROLI G., MEINER A. Landscapes in transition: An account of 25 years of land cover change in Europe, 2017.
11. BIELECKA E., CIOLKOSZ A., editors. Land cover structure in Poland and its changes in the last decade of $20^{\text {th }}$ century, 2004.

12. GUERRA C.A., ROSA I.M.D., PEREIRA H.M. Change versus stability: are protected areas particularly pressured by global land cover change? Landscape Ecology, 34 (12), 2779, 2019.

13. MELENDEZ-PASTOR I., HERNÁNDEZ E.I., NAVARRO-PEDREÑO J., GÓMEZ I. Socioeconomic factors influencing land cover changes in rural areas: The case of the Sierra de Albarracín (Spain). Applied Geography, 52, 34, 2014.

14. TRISURAT Y., SHIRAKAWA H., JOHNSTON J. Landuse/land-cover change from socio-economic drivers and their impact on biodiversity in Nan Province, Thailand. Sustainability, 11 (3), 649, 2019.

15. CADAVID RESTREPO A.M., YANG Y.R., HAMM N.A.S., GRAY D.J., BARNES T.S., WILLIAMS G.M., SOARES MAGALHAES R.J., MCMANUS D.P., GUO D., CLEMENTS A.C.A. Land cover change during a period of extensive landscape restoration in Ningxia Hui Autonomous Region, China. Sci Total Environ, 598, 669, 2017.

16. LI J., WANG Z., LAI C., WU X., ZENG Z., CHEN X., LIAN Y. Response of net primary production to land use and land cover change in mainland China since the late 1980s. Sci Total Environ, 639, 237, 2018.

17. LI Z., REN Y., LI J., LI Y., RYKOV P., CHEN F., ZHANG W. Land-use/cover change and driving mechanism on the west bank of Lake Baikal from 2005 to 2015 - a case study of Irkutsk city. Sustainability, 10 (8), 2904, 2018.

18. PRIESS J.A., SCHWEITZER C., WIMMER F., BATKHISHIG O., MIMLER M. The consequences of land-use change and water demands in Central Mongolia. Land Use Policy, 28 (1), 4, 2011.

19. MENDOZA-PONCE A., CORONA-NÚÑEZ R., KRAXNER F., LEDUC S., PATRIZIO P. Identifying effects of land use cover changes and climate change on terrestrial ecosystems and carbon stocks in Mexico. Global Environmental Change, 53, 12, 2018.

20. CALZADA L., MEAVE J.A., BONFIL C., FIGUEROA F. Lands at risk: Land use/land cover change in two contrasting tropical dry regions of Mexico. Applied Geography, 99, 22, 2018.

21. SLEETER B.M., SOHL T.L., LOVELAND T.R., AUCH R.F., ACEVEDO W., DRUMMOND M.A., SAYLER K.L., STEHMAN S.V. Land-cover change in the conterminous United States from 1973 to 2000. Global Environmental Change, 23 (4), 733, 2013.

22. GONG J., YANG J., TANG W. Spatially explicit landscape-level ecological risks induced by land use and land cover change in a national ecologically representative region in China. Int. J. Environ. Res. Public Health, 12 (11), 14192, 2015.

23. PENG J., ZONG M., HU Y.N., LIU Y., WU J. Assessing landscape ecological risk in a mining city: a case study in liaoyuan city, china. Sustainability, 7 (7), 8312, 2015.

24. HILGARD J.E. The advance of population in the United States. Scribner's Mon, 4, 214, 1872.

25. KUMLER M.P., GOODCHILD M.F. The population center of Canada-just north of Toronto. In Proceedings of Geographical Snapshots of North America: Commemorating the $27^{\text {th }}$ Congress of the International Geographical Union and Assembly; JANELLE D.G., Ed. The Guilford Press: New York, NY, 275, 1992. 
26. ZHANG Y., ZHANG J., YANG Z., LI J. Analysis of the distribution and evolution of energy supply and demand centers of gravity in China. Energy Policy, 49, 695, 2012.

27. POCEWICZ A., NIELSEN-PINCUS M., GOLDBERG C.S., JOHNSON M.H., MORGAN P., FORCE J.E., WAITS L.P., VIERLING L. Predicting land use change: comparison of models based on landowner surveys and historical land cover trends. Landsc. Ecol., 23 (2), 195, 2007.

28. SANG X., GUO Q., WU X., FU Y., XIE T., HE C., ZANG $\mathrm{J}$. Intensity and stationarity analysis of land use change based on CART algorithm. Sci. Rep., 9 (1), 12279, 2019.

29. BREIMAN L. Random forests. Mach. Learn., 45 (1), 5, 2001.

30. CUTLER D.R., EDWARDS T.C., BEARD K.H., CUTLER A., HESS K.T., GIBSON J., LAWLER J.J. Random forests for classification in ecology. Ecology, 88 (11), 2783, 2007.

31. BELGIU M., DRĂGUȚ L. Random forest in remote sensing: a review of applications and future directions. ISPRS J. Photogramm. Remote Sens., 114, 24, 2016.

32. HAYES M.M., MILLER S.N., MURPHY M.A. Highresolution landcover classification using random forest. Remote Sens. Lett., 5 (2), 112, 2014.

33. RODRIGUEZ-GALIANO V.F., GHIMIRE B., ROGAN J., CHICA-OLMO M., RIGOL-SANCHEZ J.P. An assessment of the effectiveness of a random forest classifier for land-cover classification. ISPRS J. Photogramm. Remote Sens., 67, 93, 2012.

34. GHIMIRE B., ROGAN J., MILLER J. Contextual landcover classification: incorporating spatial dependence in land-cover classification models using random forests and the Getis statistic. Remote Sens. Lett., 1 (1), 45, 2010.

35. CHAN J.C.-W., PAELINCKX D. Evaluation of random forest and Adaboost tree-based ensemble classification and spectral band selection for ecotope mapping using airborne hyperspectral imagery. Remote Sens. Environ., 112 (6), 2999, 2008

36. HUANG Y. Understanding China's belt \& road initiative: motivation, framework and assessment. China Econ. Rev., 40, 314, 2016.

37. ZHAI F. China's belt and road initiative: a preliminary quantitative assessment. J. Asian Econ., 55, 84, 2018.

38. XI J. Work together to build the silk road economic belt and the $21^{\text {st }}$ century maritime silk road: speech at the opening ceremony of the belt and road forum for international cooperation (14 May 2017, Beijing). China Econ. Wkly., 20, 54, 2017.

39. LI P., QIAN H., HOWARD K.W.F., WU J. Building a new and sustainable "silk road economic belt". Environ. Earth Sci., 74 (10), 7267, 2015.

40. ZHANG Y., ZHANG J.-H., TIAN Q., LIU Z.-H., ZHANG H.-L. Virtual water trade of agricultural products: a new perspective to explore the Belt and Road. Sci. Total Environ., 622-623, 988, 2018.

41. SUOCHENG D., ZEHONG L., YU L., GUANGYI S., HUILU Y., JUANLE W., JUN L., QILIANG M., YONGBIN H. Resources, environment and economic patterns and sustainable development modes of the silk road economic belt. J. Resour. Ecol., 6 (2), 65, 2015.

42. NATIONAL DEVELOPMENT AND REFORM COMMISSION. Plan for Construction of China-MongoliaRussia Economic Corridor. Available online: http://www. scio.gov.cn/ztk/wh/slxy/htws/Document/1491208/1491208. htm.

43. MELENDEZ-PASTOR I., HERNÁNDEZ E.I., NAVARRO-PEDREÑO J., GÓMEZ I. Socioeconomic factors influencing land cover changes in rural areas: the case of the Sierra de Albarracín (Spain). Appl. Geogr., 52, 34, 2014.

44. EEA. Land-Use Scenarios for Europe: Qualitative and Quantitative Analysis on a European Scale, EEA Technical Report 9/2007; European Environmental Agency: Luxembourg, 2007.

45. HUANG Y. Understanding China's Belt \& Road Initiative: Motivation, framework and assessment. China Economic Review, 40, 314, 2016.

46. ZHANG X., HU Y., ZHUANG D., QI Y., MA X. NDVI spatial pattern and its differentiation on the Mongolian Plateau. J. Geogr. Sci., 19 (4), 403, 2009.

47. PETERSON L.K., BERGEN K.M., BROWN D.G., VASHCHUK L., BLAM Y. Forested land-cover patterns and trends over changing forest management eras in the Siberian Baikal region. For. Ecol. Manag., 257 (3), 911, 2009.

48. SHI H., GAO Q., QI Y., LIU J., HU Y. Wind erosion hazard assessment of the Mongolian Plateau using FCM and GIS techniques. Environ. Earth Sci., 61 (4), 689, 2009.

49. FANG J., BAI Y., WU J. Towards a better understanding of landscape patterns and ecosystem processes of the Mongolian Plateau. Landsc. Ecol., 30 (9), 1573, 2015.

50. BONTEMPS S., BOETTCHER M., BROCKMANN C., KIRCHES G., LAMARCHE C., RADOUX J., SANTORO M., VANBOGAERT E., WEGMÜLLER U., HEROLD M., ACHARD F., RAMOINO F., ARINO O., DEFOURNY P. Multi-year global land cover mapping at $300 \mathrm{~m}$ and characterization for climate modelling: achievements of the land cover component of the ESA climate change initiative. ISPRS-Int. Arch. Photogramm. Remote Sens. Spat. Inf. Sci., XL-7/W3, 323, 2015.

51. MOUSIVAND A., ARSANJANI J.J. Insights on the historical and emerging global land cover changes: the case of ESA-CCI-LC datasets. Appl. Geogr., 106, 82, 2019.

52. LI S., WANG T., YAN C. Assessing the role of policies on land-use/cover change from 1965 to 2015 in the Mu Us Sandy Land, Northern China. Sustainability, 9 (7), 1164, 2017.

53. LIU X., YU L., SI Y., ZHANG C., LU H., YU C., GONG P. Identifying patterns and hotspots of global land cover transitions using the ESA CCI Land Cover dataset. Remote Sens. Lett., 9 (10), 972, 2018.

54. ZHANG L., JIN G., WAN Q., LIU Y., WEI X. Measurement of ecological land use/cover change and its varying spatiotemporal driving forces by statistical and survival analysis: a case study of Yingkou City, China. Sustainability, 10 (12), 4567, 2018.

55. PHIRI D., MORGENROTH J., XU C. Long-term land cover change in Zambia: an assessment of driving factors. Sci. Total Environ., 697, 134206, 2019.

56. ZENG F.-W., COLLATZ G., PINZON J., IVANOFF A. Evaluating and quantifying the climate-driven interannual variability in global inventory modeling and mapping studies (GIMMS) normalized difference vegetation index (NDVI3g) at global scales. Remote Sens., 5 (8), 3918, 2013.

57. LIU C., MELACK J., TIAN Y., HUANG H., JIANG J., FU X., ZHANG Z. Detecting land degradation in eastern china grasslands with time series segmentation and residual trend analysis (TSS-RESTREND) and GIMMS NDVI3g data. Remote Sens., 11 (9), 1014, 2019.

58. MIAO L., YE P., HE B., CHEN L., CUI X. Future climate impact on the desertification in the dry land asia using AVHRR GIMMS NDVI3g data. Remote Sens., 7 (4), 3863 , 2015. 
59. DUAN C., SHI P., SONG M., ZHANG X., ZONG N., ZHOU C. Land use and land cover change in the Kailash Sacred Landscape of China. Sustainability, 11 (6), 1788, 2019.

60. CADAVID RESTREPO A.M., YANG Y.R., HAMM N.A.S., GRAY D.J., BARNES T.S., WILLIAMS G.M., SOARES MAGALHÃES R.J., MCMANUS D.P., GUO D., CLEMENTS A.C.A. Land cover change during a period of extensive landscape restoration in Ningxia Hui Autonomous Region, China. Sci. Total Environ., 598, 669, 2017.

61. MO W., WANG Y., ZHANG Y., ZHUANG D. Impacts of road network expansion on landscape ecological risk in a megacity, China: a case study of Beijing. Sci. Total Environ., 574, 1000, 2017.

62. WANG W., ZHANG M., LI P. Exploring temporal and spatial evolution of global energy production and consumption. Renew. Sustain. Energy Rev., 30, 943, 2014.

63. LIAW A., WIENER M. Classification and regression by random forest. R. News, 2, 18, 2002.

64. LAWRENCE R.L., WOOD S.D., SHELEY R.L. Mapping invasive plants using hyperspectral imagery and Breiman Cutler classifications (random forest). Remote Sens. Environ., 100 (3), 356, 2006.

65. COHEN J. A coefficient of agreement for nominal scales. Educ. Psychol. Meas., 20 (1), 37, 1960.

66. YIN H., PFLUGMACHER D., LI A., LI Z., HOSTERT P. Land use and land cover change in Inner Mongoliaunderstanding the effects of China's re-vegetation programs. Remote Sens. Environ., 204, 918, 2018.

67. LI G., WANG J., WANG Y., WEI H., OCHIR A., DAVAASUREN D., CHONOKHUU S., NASANBAT E. Spatial and temporal variations in grassland production from 2006 to 2015 in Mongolia along the China-Mongolia railway. Sustainability, 11 (7), 2177, 2019.

68. LECHNER A.M., CHAN F.K.S., CAMPOS-ARCEIZ A. Biodiversity conservation should be a core value of China's Belt and Road Initiative. Nat Ecol Evol, 2 (3), 408, 2018.

69. FAN P., CHEN J., JOHN R. Urbanization and environmental change during the economic transition on the Mongolian Plateau: Hohhot and Ulaanbaatar. Environ. Res., 144, 96, 2016.

70. NATIONAL STATISTICAL OFFICE OF MONGOLIA. Available online: http://www.nso.mn/.

71. BLAM Y., CARLSSON L., OLSSON M.O. Institutions and the Emergence of Markets-Transition in the Irkutsk Forest Sector, Interim Report IR-00-017; International Institute for Applied Systems Analysis: Laxenburg, Austria, 2000.

72. OUYANG Z., ZHENG H., XIAO Y., POLASKY S., LIU J., XU W., WANG Q., ZHANG L., XIAO Y., RAO E., JIANG L., LU F., WANG X., YANG G., GONG S., WU B., ZENG Y., YANG W., DAILY G.C. Improvements in ecosystem services from investments in natural capital. Science, 352 (6292), 1455, 2016.

73. SFA. Annual Report of National Forestry (2000-2015); State Forestry Administration of China: Beijing, China, 2015.
74. UCHIDA E., XU J., ROZELLE S. Grain for green: costeffectiveness and sustainability of China's conservation set-aside program. Land Econ., 81 (2), 247, 2005.

75. LI M. Problems and countermeasures in implementing sandstorm source control project in and around Beijing and Tianjin. J. Beijing For. Univ., 2004.

76. LIU J., LI S., OUYANG Z., TAM C., CHEN X. Ecological and socioeconomic effects of China's policies for ecosystem services. Proc. Natl. Acad. Sci. U.S.A., 105 (28), 9477, 2008.

77. XU Z., XU J., DENG X., HUANG J., UCHIDA E., ROZELLE S. Grain for green versus grain: conflict between food security and conservation set-aside in China. World Dev., 34 (1), 130, 2006.

78. FERNÁNDEZ-GIMÉNEZ M.E. Landscapes, Livestock, and Livelihoods: Social, Ecological, and Land-Use Change Among the Nomadic Pastoralists of Mongolia; University of California: Berkeley, CA, 1997.

79. FERNANDEZ-GIMENEZ M.E. Land use and land tenure in Mongolia: a brief history and current issues. In Proceedings of Rangelands of Central Asia: Proceedings of the Conference on Transformations, Issues, and Future Challenges; BEDUNAH D.J., MCARTHUR E.D., FERNANDEZ-GIMENEZ M., Eds., US Department of Agriculture, Forest Service, Rocky Mountain Research Station: Fort Collins, CO, 30, 2006.

80. OJIMA D., CHULUUN T. Policy changes in Mongolia: implications for land use and landscapes. In Fragmentation in Semi-Arid and Arid Landscapes: Consequences for Human and Natural Systems; GALVIN K.A., REID R.S., BEHNKE R.H., HOBBS N.T., Eds., Springer: Dordrecht, NL, 179, 2008.

81. MNE. State of the Environment-Mongolia; United Nations Environment Programme: Klong Luang, Thailand, 2001.

82. MNE. Mongolia: State of Environment, 2004-2005 Report; MNE: Ulaanbaatar, Mongolia, 2006.

83. KORTELAINEN J., KOTILAINEN J. Ownership changes and transformation of the Russian pulp and paper industry. Eurasian Geogr. Econ., 44 (5), 384, 2003.

84. WILLIAMS R.A., KINARD J.C. A strategy for economic development of the forestry sector in Tomsk, Russia. J. For., 101, 36, 2003.

85. SEILER A. Ecological effects of roads: a review; Swedish University of Agricultural Sciences Uppsala: 2001.

86. SEILER A., FOLKESON L., editors. Habitat fragmentation due to transportation infrastructure : COST 341 national state-of-the-art report Sweden, 2006.

87. OUYANG Z., ZHENG H., XIAO Y., POLASKY S., LIU J., XU W., WANG Q., ZHANG L., XIAO Y., RAO E., JIANG L., LU F., WANG X., YANG G., GONG S., WU B., ZENG Y., YANG W., DAILY G.C. Improvements in ecosystem services from investments in natural capital. Science, 352 (6292), 1455, 2016. 
